\title{
Orphic Metamorphoses*
}

\author{
Andrew Feldherr \\ Princeton University
}

In 1824, the young Heinrich Heine paid a visit to Goethe, already a pillar of world literature, at his home in Weimar. After he and the master had talked about the weather and the attractions of the poplar alley linking Weimar to Jena, the older poet condescended to ask what his young visitor was working on. Heine brightly replied that he was, "working on a Faust." At that point an extremely displeased Goethe asked him whether he perhaps had some other business to attend to in Weimar. ${ }^{1}$ The brashness with which Heine proposed re-making Goethe's most distinctive poetic creation as though it were just

\footnotetext{
A first version of this paper was presented in July, 2015, at the conference from which this volume originates. A fuller, final, draft was submitted in January 2016, and it was shortly afterwards that I became aware of Shane Butler's The Ancient Phonograph. Butler's brilliant treatment there of how sonic effects call forth their authors in this episode, which builds in turn on his 2011 analysis of the Orpheus story as an account of the experience of reading, shares many interests and emphases with the interpretation to follow, and I gladly acknowledge his priority. I hope that the paths taken and some of the specific readings will be different enough for this article still to have value as a complement to his work.

1 So the event is recorded by Heine's brother Maximilian [Heine $(1868,122-3)$ ]; according to Heinrich they talked merely about the quality of the Saxon plums.
} 
another subject to treat $\mathbf{-} \mathbf{a}$ Faust $\mathbf{-}$ seems to find a parallel in Latin literature when the poet Ovid appropriates Orpheus as the central figure of the tenth book of his Metamorphoses. For forty years before Vergil, who rivals Goethe in the rapidity with which he was proclaimed a classic, made Orpheus quite literally central to his own poetic identity while at the same time quite probably working one of the most consequential mythical transformations in classical literature. For the Orpheus of the Georgics who perhaps here first loses his dead wife Eurydice for the second time, ${ }^{2}$ at once looks back to the lonely lover Gallus who ends the Eclogues and ahead to Aeneas' future separations from Creusa and Dido.

Appropriately the relationship between Ovid's Orpheus and Vergil's has become a synecdoche for expressing the comparison between the poets themselves, usually to illustrate the ways in which Ovid was no Vergil. The rhetorical maneuvers and shear wordiness of the Met.'s Orpheus both demonstrate and figure the perceived superficiality and "over-explicitness" ${ }^{3}$ of Ovid himself, especially in contrast to the pathos of the Vergilian original. Vergil never allows us to hear Orpheus singing, but only, as I will describe, the echoes of his song; and it takes a mere 72 lines to go full circle from the river where Eurydice perishes to the one whose banks the lyre of the dead Orpheus fills with the sound of her name, a textual model perhaps of the uncrossable rivers that hold her in the underworld. And the story is further set apart in the sense that it is not told by the main poetic voice but by that slipperiest of narrators, Proteus. By contrast Ovid's Orpheus dominates an entire book of the poem, and instead of retreating as in Vergil from the surface narrative through his own failure to speak directly or be directly spoken about, this new auctor (10.83) seems to take over the voice of the poet, giving

\footnotetext{
Contra Heath (1994).

3 For this formulation of a common critique, see Hinds (1987, 4-11).
} 
not only the longest reported speech in the poem, but one that seems to go back to the beginning and re-cast the entire poem and the entire literary career of the poet himself. In Vergil's case it is surprising to recognize that you have never heard Orpheus speak, in Ovid's it can be difficult to remember that Ovid and not Orpheus is the poet of Metamorphoses.

Ovid's treatment of Orpheus has become among the epic's most intensely studied sequences. Its self-referential capacities, as a metamorphic epic embedded within Metamorphoses, have made it a valuable tool for working out Ovid's conception of the nature and role of his own epic by a process of comparison and contrast. The figure of Orpheus can be the generic prototype of the poet, but his remarkably varied and Protean mythological career make him nevertheless a useful figure for highlighting what is distinctive in any particular poet's persona. Hence in Ovid we meet a reformed lover, now speaking inevitably in hexameters, and composing a poem of which he is not the subject, one indeed that ingeniously weaves together a number of disparate tales all of which, coincidentally, conclude with a transformation. Nevertheless Orpheus' own desires shine through every story he tells, making many of their characters potential emanations of his own presence, as much as he is of Ovid's.

For these reasons, nearly all large scale critical re-imaginings of Ovid's poem have paid close attention to an episode where so many central Ovidian themes come together: eroticism and language, art as representation and replacement, and the nature of transformation itself. In one of the most wide-ranging and influential of these readings, Micaela Janan argues that Orpheus' ultimately unattainable desire to understand and re-configure his own experience of eros through language reveals the limits of linguistic expression and the power of the author. This powerfully deconstructive reading has influenced Hardie's interpretation of the episode within the dynamic of presence and absence that unites Ovid's entire poetic project, as well as 
Oliensis'exploration of the place of the subconscious in the construction of Latin poetry. More recently still, Elizabeth Young has convincingly interpreted the episode as a parable for the rise of an imperial literary history that at once writes a history of all earlier literary production with itself as telos, and symbolically explores the relationship between writing as a permanent medium and the oral poetics of presence and change it supplants.

All of these analyses also strikingly privilege the intratextual over the intertextual. While comparison with Vergil used to be the starting point for readings of the episode, many of which to be sure aimed only at what may seem in comparison, and in hindsight, rather limited and limiting formalist appreciations of Ovid's poetic aims and means, these more ambitious recent studies orient themselves by and large to themes and problems privileged within Ovid's own poetic oeuvre. My aim here will similarly be to highlight a theme that unifies multiple aspects of Ovid's treatment of the arch-poet, the pursuit of immortality. This emphasis seems inevitable given the myth of the poet whose song aims to re-animate the dead. But the presence of a Vergilian model again gives a specific focus to Ovid's handling of this very general motif: the question of how poetry does and does not transcend the limits of death becomes bound up with the dynamics of poetic succession. An Ovidian voice in the episode may seem to emerge at the expense of an awareness of a Vergilian presence. So too, since the survival of a literal voice becomes the means of Orpheus' own survival, its circumscription within any specific text can itself become a problem in ways suggested by Heine's reply to Goethe: Ovid's Orpheus reminds us that Vergil's depiction of the poet constitutes merely an Orpheus, not the Orpheus. Conversely, an ability to recognize this transcendent mythical figure will be sharpened through Ovid's engagement with the way Vergil had already articulated the problem of poetic survival. My discussion will have two parts, each focusing on Ovid's handling of one specific technology for triumphing over 
death: the first section will thus focus on the manifestation of immortality through poetic performance and the second on sexuality and reproduction. As will already be seen, this very pairing of emphases in Ovid's narrative recalls the tension in Vergil's didactic poem between a response to death that involves the evocation of a single, lost, human life and another based on generational replacement. ${ }^{4}$

\section{I.}

The reader of Ovid's Metamorphoses too learns to see in the poem's central theme a dialectic between loss and survival, but a dialectic whose terms are themselves continually shifting. The single individual survives as, or is replaced by, a persistent type. Daphne is transformed into a laurel and all laurels, though she may or may not still be Daphne. The results of metamorphosis are eternal and/or reproducible, because they are things that last forever, like a river (just don't try to step into it twice), or a statue that can survive or be copied, or trees or animals that can replicate themselves without the variety that attaches to human offspring.

The problems of survival parsed through all the changes in this paradigm extend directly to the challenges of apprehending Ovid's own text. As we may ask of the laurel or the wolf whether the thing here really is the figure in the story, so we may identify Ovid's poetic opus with a present reality, the text subsisting as a physical presence before the reader, or with its own narrative, that lost past that seems to reveal the transience of present artifacts by pulling them back into a story world of change.

\footnotetext{
${ }^{4}$ I am indebted for the language in which I sketch this opposition to Batstone (2006, 127), although his own argument stresses the instability of such oppositions.
} 
The dualities of metamorphoses have proven especially useful for conceptualizing the relationship between the poem's written and oral aspects. The text that seemingly remains the same recalls those works of art or indeed inscriptions that constitute the permanent, transformed bodies of figures like Niobe or Phaethon. The spoken voice seems to summon up the presence of the poet and perhaps to infuse otherwise mute and meaningless matter with the ability to signify lost or forgotten narratives. Yet in a poem that pays such attention to re-performance and to the nuances and intentions that emerge from each act of narrating, the idea of an immutable text comes into question. Ovid's narrators ring many changes on myths familiar from written narratives and whose specific textual versions are immediately recognizable. Ovid's text freezes all these tendentious, partial, and improvisational vocalizations of myth in a permanent form, yet his own epic of course enters into an intertextual world where it will be changed into new texts over the course of time. And perhaps the text that achieves true permanence will itself cease to be alive. In the poem's epilogue the song as material object is no more eternal than the other physical monuments that are subject to time's power. Indeed a papyrus lasts much less long than a pyramid. What gives the text its immortality, what makes Ovid's written nomen indestructible, ${ }^{5}$ will be its apprehension as the surviving presence of the poet - when the praesagia of the poet, that alone authorize his claims about the future, are read, are taken up through the voice of the people, and he achieves a spoken presence as fama (15.878-9). The very reading of these lines therefore fulfills the prophecy they contain, or at least gives the poet's audience grounds for construing the words' oral performance as his survival. In the poem's final word,

nomenque erit indelebile nostrum, 15.876: I feel justified in terming this the poet's "written" nomen because indelebile, even if metaphorical, evokes the name as a physical presence otherwise capable of destruction. 
vivam, meaning and enactment come together as the poet is brought to life through the very utterance of his claim. And we may perhaps see the entity who partakes in this future life not simply as the human poet proclaiming his immortality, but as the book itself announcing its animation. ${ }^{6}$ Yet the realization of the poet's future ("I shall live") within the reader's present cannot itself stop the flow of time, and we may also choose to see the life of the author, and of his book, balanced precariously against the possibility of silence, as the uncertain real future takes over from the apprehension of a now that miraculously elides the difference between the present and the future of the past.

The shifting properties of script and performance provide one locus for apprehending how the opposition between disappearance and immortalization generated by the poem's metamorphic subject affects how we understand its own status as a physical presence in our world. But in this paper I want to zero in on the voice in its own right, and explore how Ovid uses it to illustrate the mechanisms and risks of poetic survival. I take my start from a metamorphosis which challenges assumptions that the transformed subjects of Ovid's narrative acquire permanence, if not presence, in their new manifestations, and connects this issue with the signifying power of language in its spoken and written form: the transformation of Adonis into a windflower that ends Orpheus' song, as the prediction of his own immortality does Ovid's. ${ }^{7}$

In this case, the monument for the lost individual seems to have taken on the very transience that such material survival might seem to remedy. A physical flower may seem to preserve the fleeting beauty of youth, embodying the metaphorical

Cf. Hardie $(2000,94)$, though with different emphasis: "the living presence of the poet is the text."

7 For an earlier argument describing how Adonis and Orpheus as mythical figures associated with re-birth look forward to Ovid's own projected immortality, see M.D. Thomas (1998, 106-9). 
flos aetatis, or else to reify its essential impermanence. Earlier in Orpheus' song, for example, Hyacinthus had become the hyacinth. But in that case the short life of real flowers is left unspoken: the emphasis falls on endurance "durat" (10.218), and the reference to an annual festival helps link this paradox of permanent flowering to a natural cycle of rebirth. Here, though the goddess herself identifies a festival that will reproduce not the lost boy but Venus' own sense of loss, specifically the sound of her mourning (annua plangoris ... simulamina nostri, 10.727), the flower itself seems ambivalently related to it. ${ }^{8}$ The manuscripts suggestively divide over whether an et links the flower to the festival, or an at contrasts them.

When the poet describes the metamorphosis, as opposed to the goddess' predicting it, he highlights destruction as inevitably linked to re-birth. The polarity between death and preservation takes symbolic form when the goddess scatters the blood with nectar, but the poet's description by underlining the temporality of the process rather than the immortal product, seems again to memorialize the youth only through change itself. By contrast to the divine nectar that triggers it, the flower's coming into being is likened to a bubble. The poet then goes on to describe how the flower arises in no less than a full hour. The goddess may be thinking in terms of recurring seasons, but, as elsewhere in the poem, the narrator collapses that to a single point of time by translating a Greek season (bora) as a Latin hour (10.734)..$^{9}$ Against the rebirth promised by the simile of the pomegranate, ${ }^{10}$ with its pliant or "sluggish" rind (lento, 10.736), the flower seems to outdo all others in its ephemerality, lasting not a season, nor even the hour it takes for

\footnotetext{
8 For an analysis of how Venus' pre-occupation with herself seems to write Adonis out of his own memorial, see Pavlock $(2009,100-1)$.

9 cf. Barchiesi $(2005,241)$ on 2.26 .

10 Pavlock $(2009,101-2)$.
} 
this original generation. "The very winds that name it destroy it,"(10.739). The reference to the flower's existence immediately suggests its destruction (at least to the narrator). And the commemoration willed by the goddess stands at odds with both the mortal youth she mourns - for a while - and with the monument that she creates. The narration itself seems to make the flower disappear, while the divine view sees continuity in recurrence. In the telling then, the monument simply becomes part of a story that has reached its end, as opposed to the divine "future perfect" perspective. Finally, unlike the hyacinth, the anemone would never name Adonis, nor is it even named itself directly. Even to recover the identity of the flower demands re-translating Ovid's Latin into Orphic Greek and recognizing in venti, the eponymous anemoi that name the anemone.

It is not surprising then that interpretations of this pivotal metamorphosis have emphasized its deconstructive capacities and applied them outward to the poetic products of both Orpheus and Ovid himself. Metamorphic artifacts do not immortalize the dead in the flesh - there is no Adonis in the flower. They can only vanish, and by extension the poet does not name even the non-existent image. As Micaela Janan, has shown, all language seems to have lost its power to signify, though it can perhaps imitate its referents in the process of its passing away. Elizabeth Young offers perhaps the most ambitious interpretation of such representations of mortality when she argues that Ovid's Orpheus narrative figures his death as inscription - a translation into writing typical of the Augustan ambition to construct a totalizing and permanent story of everything that ends in the imperial present., that nevertheless silences all its subjects even as it inscribes them.

However, as Joseph Reed notes in his new commentary, the poet supplies the missing name of the flower in the very first line of the next book with the description of Orpheus leading 
animosque ferarum (11.1). This "word play"11 may seem retrospectively to diminish the semiotic inadequacies of Orpheus' conclusion, as a new level of poetic narrative rescues the signifying power of his song, and with it perhaps the lost life of the "exanimis" Adonis (10.721). And to start my argument, I would like to make two points about the particular form this resurrection takes. First, the meaning of animosque has nothing to do with windflowers, nor indeed with very much else - animosque ferarum seems simply an overblown periphrasis for feras. By contrast the word answers the riddle of the missing sign largely through its sound. Latin animus may or may not mean the same as the Greek anemos, but the echo connects them, and that link allows us to see the windflower as restoring, or at least evoking the lost anima of Adonis himself.

Any reader, of course, could well argue against the capacity of this sonic re-duplication to evoke the dead youth, beginning perhaps by querying the identity between the animus and the anima, and that is in part my point, the assonantial associations that extend the signifying power of words are inevitably uncertain, and fleeting, all the more so when we imagine them heard in performance rather than immortalized on the page. Hardie observes that already nomina in the final line of Orpheus' song seems at once to name and avoid naming by suggesting the sounds of the anemone. In a complementary way the letters on the page seem to ask palindromically whether this anemone can serve for a soul animon? But this too suggests that the components that make up words, whether as sounds or elements, are already undergoing dissolution and any apparent manifestation of souls in names can be as random or misleading as the deceptive presence of ignis in lignis, according to Lucretius (DRN 1.901).

\footnotetext{
$\overline{11 \quad \operatorname{Reed}(2014,303) .}$
} 
My second point about this sonic effect also involves animosque's own partial echo of nomina at the bridge between Orpheus' song and Ovid's resumption of the role of narrator. Along with the semantic evocation of an absent third party through a chain of sonic likenesses, sound effects can continue to evoke or echo speaking presences in the direct sensory experience of the audience. Animosque may or may not remind you of nomina or the anemone, much less restore the soul of exanimis Adonis, but if we interpret the word under the influence of the windy anemos then at the same time as it echoes Orpheus, the word not only names itself but manifests its presence as breath. The breath of any speaker through which the poem is articulated becomes a physical manifestation of the animus. And within the narrative as well the crucial agency of wind helps to set the chain of connections between the dead and the living in motion: the flower in its creation is compared to a "glistening bubble [is] wont to rise from tawny mud," (10.733-4). ${ }^{12}$ And there is a similar continuity at the narratological level. Ovid is describing a poetic performance, one that indeed happened in the past and whose ending is all too imminent, yet he is at the same time giving one. Such a mise-en-abime ${ }^{13}$ may re-inforce the aural continuity that similarly bridges the gap between books. The sonic presence of the voice contradicts the sense of finality imposed by the ending of the story, even as the same voice that had been Orpheus' describing the death of Adonis now becomes Ovid's describing the death of the previous narrator. Again the breath that names simultaneously destroys. Young convincingly demonstrates that Orpheus' death seems to happen through inscription, but the pre-requisite for this is that his own song be lost in a clamor of other noises (11.16), and

12 Pavlock $(2009,101)$ perceptively compares the "bubble," bulla, to the amulet that boys put away at their transition to adulthood.

13 The expression is used in a somewhat different sense of Orpheus' song by Pavlock $(2009,89)$. 
the image of his being written may have as much to do with his shift from the role of narrator to being the subject of Ovid's narrative.

This other aspect of the restorative presence of sound may operate in tandem with the way words semantically re-animate Adonis through assonance. But it also raises interestingly complementary interpretative challenges. In place of working outward from a narrative of the distant and unbelievable past and then allowing us to hear it, here the sound comes first. This unmistakeable sensory experience invites interpretation of the past. And if the uncertainties of sonic resemblance raised a problem for an author, whose own words were likely to decompose as the wind of a new speaker's voice blows through them, here we might consider the problem from the perspective of the present speaker who is made aware of another's words emerging from his mouth. One Roman epitaph chillingly links recitation to possession: "lo," it makes the reader himself proclaim “your voice has become mine," (quod legis, ecce, loquor, vox tua nempe mea est, Possidius, Vita Aug. 31=Anth. Lat. 721). Orpheus/Ovid's coming back to life through the speech of a reader may seem to bear a similar threat for those whose own voices become his instrument.

In the remainder of this section I would like to provide some contexts for interpreting the role of auditory presence in this passage. Specifically, I want to treat it as a way of re-positioning Ovid's poem in relation to its literary predecessors. The question of Orpheus' survival in the narrative voice of Ovid overlaps of course with a specific instance of literary reception - Vergil's Orpheus provides the inescapable intertext for Ovid's treatment. And indeed the issue of vocality already marks a central difference between the two poet's representations of this figure. As I mentioned in the introduction, to look back at Vergil's treatment from the perspective of Ovid's can highlight by contrast Orpheus' absence as a speaker in the Georgics. If Vergil 
highlights the narrative contexts that separate the reader from Orpheus, nevertheless allowing us to hear at fleeting moments his voice as Orpheus', the dynamic in Ovid's poem works in the other direction. The presence of Orpheus seems to take over the narrative so that it is the Ovidian author who seems to magically address us in the guise of Orpheus. The "now" of the narrative has been in Ovid's case displaced for the duration of the utterance. As we will see, not only does the problem of Orpheus'vocality re-develop a Vergilian dialectic about the place of poetry in time, meditation on the voice as a means of poetic survival raises questions about the nature of reality that inform and are informed by our sense of the capacities of poetry.

First let me remind you that the contrast between hearing animos in 11.1 as representing the spirits of beasts the poet "leads" as the narrative moves to a new phase, and hearing animos as the literal echo of the anemos is hardly unprepared for within the poem. Orpheus' own name seems to convey the different stages of sonic progression, summoning up the source of the voice, the ora (11.8), its medium, the aura $(10.59,11.6)$ and its destination, the aures (10.62). And complementing the transformation of his body into a written text, which Young has traced, Orpheus' death itself not only involves the question of his sonic survival, it also quite literally echoes the metamorphosis that repeats the death of Adonis, both Orpheus' description of it, and the sonic traces with which Ovid re-iterates the passage at the beginning of the new book:

$$
\begin{aligned}
& \quad \text { perque os, pro Iuppiter! illud } \\
& \text { auditum saxis intellectumque ferarum } \\
& \text { sensibus in ventos anima exhalata recessit. }
\end{aligned}
$$

(11.41-3)

As in the case of Adonis, the wind will be involved in the destruction of a soul, but that anima suggested by the anemone and named in the masculine by Ovid is itself now named here directly, as if finally resolving the thematic hints of the earlier 
passages linking the soul to the wind, and completing a process of naming by allowing not just the verbal sign for the soul to name the wind (animos anemos) but the physical wind to define the soul (ventos=anima). At the same time, again the very moment its destruction is narrated, this anima is made present here in the onomatopoetic exhalation of the breath. Thus the death of Orpheus makes the dissemination of the breath correspond not only with its presence at the moment of performance, but also with a dissolution of its signifying capacities. The mouth that had once been the source of understanding now becomes the orifice through which the merely material soul departs into its essence, the wind. The loss of a distinctly Orphic animus corresponds more sharply with the felt, and heard, presence of the breath.

But immediately this sonic presence is echoed within, and again by, the narrative as the natural world takes up the lament:

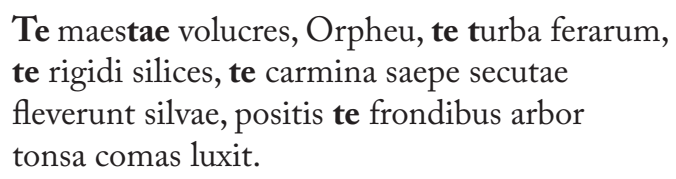

Not only does the anaphoric repetition, further projected through assonance and alliteration, take up the echo in the text, but the name Orpheus itself becomes the expression of this collective lament, as a vocative ending in heu (and this is the first and only time this vocative form is used). Again the sense of vocal presence connecting myth and reality must be qualified by a loss of distinctive voices, and indeed an encroachment on the semantic functions of language by its merely evocative ones. If the song of Orpheus could be understood miraculously by inanimate objects, now it is precisely the inhuman sounds of nature that have found their echo in Ovid's poetry. He repeats the song of the birds and rocks. And Orpheus has become the expression of lament as much as the name of a person. A similar linguistic co-existence had been predicted earlier in Orpheus' 
song, with the inscription of AIAI on the hyacinth (10.215). That this flower will later gain a competing commemorative function as the monument of Aias, demonstrates how written texts too can change over time (13.396-8). But this transformation involves more than the crowding out of one name by another: the function of writing has changed as well so that the inscription memorializes Hyacinthus and Ajax in fundamentally different ways. As Ovid will put it, AIAI records the name that designates Ajax, but it transcribes the sound of the lament made by Apollo ( haec nominis, illa querelae, 13.398). ${ }^{14}$ To read Aias represents the later tragic victim, but its sound echoes the voice of the god. So later when the also voiceless lyre of Orpheus imposes its echo of the flebile aliquid, on the poem, Janan notes the intellectual incoherence of the echo. But on the other hand, at least a flebile aliquid is something, and something whose presence in the sensory world of the audience gives it a distinctive immanence. We may recall that one specific quality of the Apolline song of the lyre, as opposed to the Bacchic flute-playing that overwhelms it, was that it gave expression to a rational voice. ${ }^{15}$

Within Ovid's poem, the tale of Echo highlights a tension between meaning and mere repetition and again shows the transformation between these two aspects of sound operating in both directions: a purposeful, rational utterance dissolves into sound, and a universal sonic effect assumes the capacity to name and evoke presence. When Echo first attempts to communicate her love in Narcissus' own words, we know the intention of the author, but perceive also the inadequacy of these casual sounds to express it (3.380-92). A few lines later, there is no longer a named Echo, but merely the voice in deserted landscapes (3.400-401). Now we have a present sonic phenomenon, and

14 Young $(2008,17-9)$ especially stresses the function of writing as a transcription of sound in this passage.

15 Plut., Alc. 2.5; Arist., Pol. 1341a21-8. 
use it to reconstruct, indeed to bring to life, a subjective presence (again assuming the lines are not interpellations). An example of this re-animation comes appropriately when Narcissus' death seems to resurrect Echo herself, whom the reader might assume had vanished as a corporeal presence. For when his farewell to his image, "vale", resounds in the forest, we assume instantly that it is not just an echo, but the voice of Echo (3.501). The sound itself reconstructs a voice which picks up the words of one lover for a non-existent image, to apply it to the lover himself at the moment that he ceases to be a body. The example of Echo, therefore, read in connection with the end of the Orpheus'story, again heightens the paradox of the vocal image, immortalizing a chain of vanished speakers at the instant of their destruction - but only if we are already prepared to hear it as a voice.

Echo's fictive farewell will itself re-emerge at the beginning of Orpheus' story, as the only utterance of Eurydice during her all too brief return to life. But before considering that passage, it is time to move outward from "echoing" as an internal phenomenon of the text, to more substantial echoes, that is the re-production of words from one text to another. Specifically I want to consider Ovid's re-articulation of Vergil's Orpheus. And my aim will be to show that the paradoxes surrounding sonic survival are themselves an echo of tensions within the poetics of the Georgics. At the same time Vergil's own presence as an author seems to add a new link in the chain of voices reanimated through sound. As Echo echoes Narcissus mourning a mere image, so Ovid echoes Vergil echoing a purely fictive Orpheus, mourning a Eurydice who is already absent when addressed. The voice either unites these speakers in the now, or prompts us to dwell on the different levels of separation between life and death, reality and fiction, and historical narrator and mythical narratee. 
We seem most fully to catch an echo of Orpheus himself in those marvelous lines describing how the poet mourns his first loss of the still unnamed Eurydice:

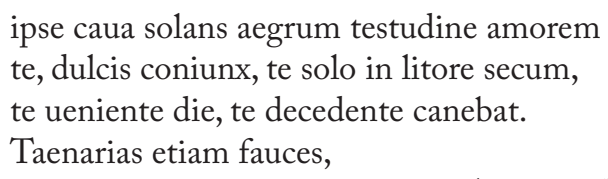

As John Arthur Hanson beautifully observed, the assonantial te appears not only where it semantically designates "you", the lost coniunx; we also hear it echo in words of quite different meaning - at the end of the coming day (veniente) and of the declining day (decedente). This provides already a good example of the pointed ambiguity of the voice that I am describing. For on the one hand we can perceive the sounds themselves as tracking the temporal progression the lines describe, as the long e of te in the arsis of the first foot fades into the minor key when echoed by short e's in the theses, where -te forms a component of words that temporally separate Orpheus from Eurydice. Again the content and rational semantic capacity of the verse co-exist uncertainly with its function as a purely emotional expression. And the crossing of limits, both temporal and spatial, gives this sonic continuity thematic importance in a poem so conscious of the right time for actions and the difference between places. As Orpheus' monothematic, indeed monosyllabic utterance, fills all of time, so the expressions that measure time, the coming and ending of the days, now express that song: each passing day says "te". Spatially the sound seems literally to arise from the first striking of the lyre (testudine), and to reach the gates of the underworld itself (Taenarias). And this resonance already accomplishes the mission of Orpheus' unrecorded infernal song, for he has fitted the underworld into the sonic pattern that brings back his lost wife $(t e)$. Finally, the naming of the wife as "you" creates a powerful narratological gravity that pulls every speaker 
into the perspective of Orpheus. The effect of an apostrophe to summon an absent presence is well known ${ }^{16}$, and we can see it at work here as the naming of Eurydice seems to configure or call up the absent addressee. But the second level of supernatural ventriloquism comes when we consider how the identification of the addressee also transforms the identity of the speaker - as the song addresses the dead coniunx as you, and makes "you" the dead coniunx, then this emotive vocalization turns every speaker, from Proteus, to Vergil, to the amicus or slave or self reading Vergil, into the Orpheus.

But for all that these verses both describe and demonstrate how the emotion of loss takes over the words of the speaker and refigures the worlds the poetry describes and within which it is performed, they bear a curiously anomalous relationship to the narrative voice of the poem where they occur. As the content of the story stresses the ultimate impossibility of crossing the rivers that bound the underworld and leave the poet alone on the other side of a threshold, so the sound that emanates from the dead poet's lyre remains within banks (ripae, 4.527), that echo the precisely designated un-Georgic space he is given for his song (Riphaeis, 4.518). And the very insistence with which Vergil or Proteus names Orpheus' song as fletus $(4.505,514)$ or questus (4.515) re-inforces the limits to its effect: the mourning may be infinitely repeated, but that repetition clarifies that its initial apparent success in persuading the shades, from the perspective of the completed narrative will end in failure. And the designation of Orpheus' song as mourning also gives it a generic identity as elegy which is consistently out of place in Vergil's own work. The elegiac figure whose continual song of love and loss mimics the ideally unchanging subject matter of a Propertius (Cynthia prima fuit, Cynthia finis erit, 1.12.20)

16 Within the vast literature on apostrophe, Alpers (2013) is an especially helpful introduction to the issues. 
provides a foil to a didactic project aimed at provoking change and distinguishing times and places.

At the end of the poem, however, Caesar thundering at the Euphrates and giving laws (iura, 4.562) seems to do for Vergil himself what that poet had done for Orpheus. He creates a spatial boundary that reveals the limits of poet's sphere of activity and simultaneously the structure of time that measures it. It is during "that time" illo tempore (4.463) poet works, and the strangely epistolary imperfects highlight the real distance between the poem's composition in the past and the present moment of its performance: the time when Vergil was writing differs from the now of its reading, whereas the sonic echoes in Orpheus' song assimilate the time in which the poetry is heard to the distant past when it was spoken. This suggests a nested structure of poetic controls as Vergil limits Orpheus, to be limited by Octavian, whose place at the bank of another river, and threatened ascent to Olympus, seem, according to the model of the poet, to hint at another Orphic reversal. Vergil plays Orpheus to Octavian whose own limits then come into view. The image of a parade of Orphic replacements moving outward from the mythical past to the poetic present to the imperial future will form an important model for how Ovid inserts himself in this tradition. When Ovid in turn re-produces the voice of Orpheus, the awareness of succession itself hints at Ovid's own distinctive moment in a sequence of time that will necessitate his replacement. When it is time to kill off Orpheus, the weapons Ovid supplies come from the Georgics themselves, the (ultra-Vergilian) arma of passing farmers, whose cattle are violently destroyed to boot.

At the same time, and literally at the same time in the narrative, the nature of the Orphic song as an almost pre-verbal instantiation of mourning coming through every attempt to measure time and space in language suggests an alternative 
temporal perspective on Orpheus. Not only is he a model whose failure to transcend limits every new protagonist will eventually reach. His is the voice that is always present now. ${ }^{17}$ And this is aspect of Orpheus' song appears more forcefully when we remember that while Proteus may describe the song in the language of elegy, in terms of sound and the techniques of apostrophe they seem rather to echo the very line with which Vergil established his own poetic voice, and which he echoes to establish the persistence of that identity at the end of the Georgics: Tityre tu patulae, recubans sub tegmine fagi (E.1.1, cf. $G$. 566). Moreover, to hear that echo recalls the way echoing itself was thematized as the source of that utterance. The name Tityrus reproduces the sound of the word psithurisma in Vergil's Greek model, and that not only designates but onomotapoetically reproduces the effects of the whispering breath itself. The Vergilian identification with Orpheus, therefore, however delimited in the georgic context, itself animates a specific mechanism of poetic memory. Vergil does not reproduce the "matter" of the Greek verse, conspicuously changing the byle from Theocritus' pine to the native Italian beech, but the sound of the verse links these two moments in literary history. And indeed both are connected not just to the ever-present sound of any performance but to a timeless natural phenomenon. ${ }^{18}$

Not only will this opposition between an essentially Vergilian Orpheus, or Orphic Vergil, and the limiting, didactic emphasis on progression and replacement, re-emerge in Ovid's treatment of the Orphic voice, but the real presence of the Vergilian intertext brings the issue of poetic succession into the

17 This aspect of my reading is deeply indebted to Parry 1972, who however sees the demonstration of Orpheus' art as "the epitome of all human art and craft, [wherein] lies the true immortality of the poem" (p. 52), whereas I prefer to stress how this vision is countered by the more literal ars that is the poem's ostensible subject.

18 On the sound effects in this line, see now especially Cucchiarelli $(2012,136)$, who also suggests an echo of the bucolic flute. 
orbit of this dialectic. Ovid may be replacing the dead Vergil, but this condemns him to be himself replaced. Or we may hear the Vergilian presence in the identity that each speaker assumes in the now of poetic utterance, but only through a model of possession that raises questions ultimately about how meaning or authorial identity persist through time.

This use of the Orpheus myth to fold issues of reception into performance makes it tempting to see other Ovidian evocations of Vergil in Orphic terms, and to note conversely how a Vergilian presence is summoned up elsewhere in Orpheus' narrative. The famous phrase Vergilium tantum vidi (Tristia 4.10.51) condemns the earlier poet of Orpheus to play Eurydice, slipping away at the very moment the young Ovid summons him back. And perhaps we can catch a further glimpse of this model of poetic succession, and mechanism of poetic persistence in that moment in Orpheus' own narrative that seems to re-visit and reverse his earlier necromantic failure. When Pygmalion's artistic illusion seems to call forth "the face of a true maiden", that line seems to call forth the true Vergil in two ways, as a visual reflection and a sonic echo. For the first, recall that Vergil himself, according to the Suetonian life (11) was "vita et ore et animo tam probum ..., ut Neapoli Parthenias vulgo appellatus sit." Simultaneously the name Vergil recurs as an echo of words that do not signify his presence, much as the earlier poet had evoked Eurydice through the assonantial half-echos of "te". Virginis est verae facies, quam vivere credas. (10.250).

In recovering the operations of this inherited opposition between song as a marker of mortality and its capacity to overcome temporal separations, I want to focus now on the figure of Eurydice, who within the poem begins the chain of mourning that will eventually resound for her own poetic mourner, Orpheus. I start though with a paradox of Orpheus' first song, the one addressed to the underworld divinities. Vergil's decision 
not to depict this song directly has been acclaimed by critics of the Metamorphoses, who detect a tone of frigidity bordering on parody in the legalism of Ovid's language. ${ }^{19}$ But Orpheus' mood-killing sophistry that he only wants to borrow Eurydice not possess her in perpetuity also raises a more serious question about time and mortality. What exactly will be the term of the lease? Or, put another way, how long a stay on earth would be enough for Orpheus? Indeed the glimpse that he gains of his beloved might be as much a fulfillment of his request as a technicality that voids it. As the song tries to express both the law and the desire that transgresses it, so its failure to achieve its ends coincides with its success.

And Eurydice herself figures this collapsing together of incompatible temporal frames - the transcendent and always repeatable instant, and its disappearance at the very moment it comes into being - in two ways, first in her own utterance and then when she is named. Another much noted difference in Ovid's treatment of this episode is that where Vergil had given Eurydice a five line lament at the moment of her return, centered on the poignant farewell, "iamque vale," (4.497), Ovid provides the Reader's Digest condensed version, "vale", which itself seems less a direct quotation than a reference to one: "she spoke her last farewell" (10.62). In doing this, the poet emphasizes the problems of temporality latent in Orpheus' contract with the gods. For the moment in which Eurydice becomes a direct presence in his own poem is reduced to a vanishing point that signifies only her passing away. And that effect is strengthened by Ovid's own appropriation of the temporal adverb "iam" that in Vergil seemingly froze the time of Eurydice's verbal presence by letting his readers experience the moment of final parting from within the frame of the narrated "now". For Ovid at once

19 For a fine and informative comparison, see Anderson (1982, 40). On legal metaphors see Reed (2013,173-4), with further bibliography. 
"echoes" iamque again in his own narrative of Eurydice's speech (iamque iterum, 10.60), as if to stress the reproduction of her voice even in his indirect account of it, but he then repeats the echo in a way that suggests the distance between the utterance and its recipient. Orpheus could already (iam, 10.62) scarcely hear the speech that its own re-production has made so inaudible, just as his own uncertain presentation of her speech as direct discourse makes it hard for his audience to tell whether they are hearing Eurydice's farewell, or simply hearing of it. In the instant of its coming into being, the word slips away from its recipient(s).

But it is not just as a voice that Eurydice creates this effect, it also emerges from the ambiguities of her own nomen. The word Eurydice first appears, in a Greek genitive form, in line 10.30. Just before Ovid had called on the divinities of the underworld to grant his request "per ... vasti silentia regni," (10.29). Thus at the instance when Eurydice becomes herself in the text, her name is also susceptible to being read as a gloss on the underworld itself. The "broad domain" her name signifies in Greek translates the Latin vasti regni, a linguistic transference intensified by the hyper-Greekness of the form Eurydices. Even at the moment when she is being called forth from the underworld, as Milton might put it, she herself is hell. It is important to note too that in this case it is the meaning of her name, not its sound, that seems to evoke the kingdom of the dead. But the reverse occurs later in the song, when Eurydice's ability to translate the powers that compel her absence is complemented by a sonic resonance. A more direct translation of dike into Latin will be ius, and seven lines later, when Orpheus promises the gods of the underworld, one of whom, Persephone, already has the cult title Eurydice, that she will always be "yours", he uses the phrase iuris erit vestri. The words iuris summons up Eurydice not only in meaning but as an assonantial echo in the same metrical sedes. (It's only a shame that Ovid could not avail himself of the English your as a 
translation of vestri.) And this same echo links the beginnings of the episode to its endings at the conclusion of Orpheus' second song. As Venus creates her transient monument for Adonis, she depicts as an inferior rival the goddess Orpheus had to supplicate: if Persephone had the power to turn a woman into a plant, she can do the same for a man. She also explicitly asserts that this gesture will defy the same fates to whom Orpheus was subject with a denial of the very assertion that Orpheus had made to limit his song: "non tamen omnia vestri/ iuris erat," (10.725). ${ }^{20}$ Note that as opposed to the first example where the translation of the actual name describes the underworld, the signifying process now works backwards. The word that designates Eurydice is absent, but her presence can be suggested by the sounds.

Ovid's Orpheus episode simultaneously evokes multiple accounts of poetic origins and transformations, finding a source for the Latin poetic presence of Ovid's recited text in some fabulous, Hellenic past. Reed and Young both describe how the sounds emanating from the Orphic head become the source for the Aeolic songs that begin multiple traditions of erotic poetry. ${ }^{21}$ At the same time, as I have tried to argue here, Ovid's echoes of Vergil's Orpheus themselves place him in a tradition of sonic continuity that finds in the echo a trope and a mechanism for the appropriation of Greek models and harmonizes all these dissonant voices in the motion of the breath. And Ovid gives this tangible phenomenon an unbelievable aetion by pegging it to the actions of a mythical presence, Echo, whose voice we can claim to hear in the responsions of nature. But the breath that I have argued optimistically seems re-born in the resonances of animus that make the second Orphic song, at least when it mer-

\footnotetext{
20 For a discussion of how Venus' echo of Orpheus' song to Persephone advertises Orpheus' presence as narrator, see Pavlock (2009, 103-4).

21 Reed (2013,312); Young $(2008,9)$.
} 
ges with Ovid's, a successful means of bringing back the dead, recalls another even more ancient story of the origins of Roman literature, ${ }^{22}$ for it was the anima of Homer that made possible Ennius' own sonic echo of Greek poetry in the hexameter.

However, as these examples show, all such narratives do more than link song to some lost but perceptible predecessor, the story itself becomes a prompt to probe certain views of nature. In the Georgics the presence of an Orphic echo contrasts with a model of agricultural reproduction based on a knowledge of the world as it is that makes it possible to replace lost lives with others. And in Lucretius, of course, the story of Ennius introduces only implicitly a poetic genealogy for the De Rerum Naturae. Rather, as Monica Gale $(2007,108-9)$ observes, the transmigration of Homer's soul prompts an inquiry into the nature of souls themselves, just as Ennius himself becomes a poet of natural philosophy. This oscillation between using nature to think about literary appropriation and literary appropriation to think about nature also emerges in Ovid's invitation to perceive the survival of animi in the sonic presences of the natural world. And the problem is rooted in a struggle between a Lucretian definition of an anima as uniquely existing only once, and an Ennian/Pythagorean model of transmigration of intact souls. When Ovid says that the winds that name the flower also destroy it, the words assimilate that flower to the soul itself, which in a key passage of Lucretius was not an eternally living essence, nor composed of breath, but rather itself destroyed by the winds who scatter the light round atoms of which it is made (3.487-509). And in that very passage the irrational vocal utterances of an epileptic give evidence of that soul's dissolution. All these vocal

22 Cf. the comments of Ahl $(1985,59)$, based on very different arguments about the poem's opening lines: "Ovid gives voice to forms that cannot speak for themselves. In doing so he is animating nature as Orpheus had done." Ahl thus finds in Orpheus an echo of the poet's title, and a sonic anagram of the mutatas ... formas with which it begins. 
sounds that re-shape the words of the past do not of course really express the animi or echo the animae of figures who perhaps, like Orpheus or Echo, were never really there in the first place, they are replacements composed of an entirely different physical substance, like a soul may be made of re-used atoms without being the same soul. And this in turn cuts away the future of any poet's voice, by making its survival depend on the will of the reader to discountenance what she knows about the world. Yet the seeming reality of poetic presences, bolstered by lessons taught through and by these mythical figures, provide just such an impression of survival. That same Ennius who claimed to have been inspired by the soul of Homer, would also in his epitaph take possession of new readers in turn, flying alive through their mouths. And in philosophical traditions, one of the essential authorities for the notion of the immortality of the soul was the possibly non-existent Orpheus himself.

This model of reception, while it is good for the author looking forward may be a quite uncomfortable one for the reader or recipient who comes to hear his own voice as another's. The tension between these two models, as Ovid struggles to impose a medium of poetic survival resistant to physical change, while at the same time raising the specter that even in doing so he has lost the fundamental aspects of his identity, emerges ultimately from these Orphic reflections on what we hear when we reproduce his song. And indeed a final internal echo reveals how the stakes of this dilemma are linked particularly to Ovid's text. For the entire scope of the poem progresses from a focus on the Ovidian animus, here masculine and strongly linked to the rational, intentional capacities of an individual author, to that same author's willed but uncertain presence in the voice of each speaker. ${ }^{23}$ Each instance of the poem's utterance as sound therefore offers a synchronic epitome of its epic motion. Not only

23 I owe this point to observations made Alexandre Hasegawa during the discussion that followed the presentation of this paper as a lecture. 
does the phrase animos ferarum thus re-echo the work's opening, perhaps reminding us further that this is now Ovid's poem not Orpheus' but it integrates this transition into the progression from a lost anima, to a present "breath", anemos, that may or may not be a soul. Again, precisely the most physically tangible manifestation of poetic performance, the breath of the speaker, that makes these aural presences seem so miraculous, also provides the material refutation of such literary metempsychosis. As Ovid, or Orpheus, might put it, the very winds that name these figures from the poetic past also destroy them.

II.

My aim in the second part of this discussion will be to integrate the problem of what sort of presence can be conveyed by the voice into the larger concern with the desire for immortality in the episode. I will concentrate on a second great transformation Ovid effects in the Vergilian Orpheus, for not only does he make him a more emphatically vocal figure, he also re-casts his desires in the amatory sphere. ${ }^{24}$ Instead of a lover whose elegiac longings were always directed towards the perpetuation of a lost past, Ovid's Orpheus seemingly moves on to greener pastures. He no longer manifests his old love but teaches new ones, and the various imagined objects of desire will serve as replacements not only for Eurydice, but also for himself. My analysis of Orpheus' sexual desire will not only suggest a link between this erotic transformation and the pursuit of immortality through poetry, it will also treat the specific means of this pursuit - sexual as opposed to "vocal" reproduction - as a trope for poetic succession. At the same time, this perspective will show how Orpheus' second song, with its own distinctive

24 However this was itself a return to a pre-Vergilian tradition of Orpheus as a pederastic poet, on which see Makowski (1996). 
mixture of generic properties, forms a bridge between the zerograde of immediate sonic utterance and the epic scope of Ovid's epic as a whole. For, as the presence of the voice instantiates and miraculously escapes the limits of physical reality, at the same time that Orpheus tries to teach lessons about time's passage, rather than experiencing them, the song as a whole signals its own subjection to temporality. ${ }^{25}$

We will begin by returning to the way that paradoxes of generic affiliation in Ovid's Orpheus extend the use of generic struggles in the Georgics to sketch different views of human temporal limits. ${ }^{26}$ In the previous section, I noted the references to lamentation and complaint in Vergil's poem that characterize Orpheus' song with the distinctive vocabulary of elegy and thus point a contrast with the more forward-looking and productive discourse of didactic poetry, which teaches you how to get on with things. ${ }^{27}$ Ovid, whose elegiac origins can frequently be glimpsed through the Metamorphoses'epic affiliations, in making the lamenting figure not the subject but the speaker of his poetry seems to be challenging Vergil by removing the representational boundaries that marginalized Orpheus, putting elegy back into hexameters rather than shutting it out. ${ }^{28}$ But he has another

25 Oliensis (2009), from a psycho-analytic perspective offers a somewhat analogous double reading of Orpheus's second song as at once a lamentation and a subconscious revelation of his guilt.

26 I should note that many generic 'strains' have been detected in this episode in previous scholarship [especially perhaps Knox (1986, 48-64)]; in what follows, though, I will emphasize one particular 'dialogue', that between elegy and didactic. For the model of generic dialogicity as a method of interpreting the poem, see especially Farrell (1992). Of particular note is Ziogas' (2013, 148-54) account of the song as a post-Hesiodic catalog poem.

27 For such elegiac intrusions see also Thomas (1988, 2.204). Bound up in the issue, of course, is the presence of the arch-elegist Gallus behind Orpheus, on which see Thomas $(1988,1.13-6)$.

28 For other, very influential, readings of how Orpheus re-forms Ovid's poetic career, see especially Leach (1974, 119-25), Janan (1988, 114-6), and Nagle $(1988,111-21)$. 
tactic up his sleeve in this generic skirmish. For his Orpheus does not just recall and expand the original elegiac voice; he also figures the same sequence of succession and condemnation that Vergil puts in motion. At the moment when Orpheus takes over as the narrator of Ovid's poem, he has moved on. Leaving the language of mourning and desire for Eurydice behind, he is now a poet with a didactic mission. Vergil's Orpheus masters time with language - resisting the markers of time's passage by re-writing them as elegiac lament - but Ovid's experiences time's transformative powers. And the effect of its passage is both to remove him from the actual sphere of erotic activity (at least with females) and to turn him into an author (10.79-85). During that same time, Orpheus has shut himself off from the sexual preference that Ovid himself helps establish as canonical for elegy, rejecting women and turning to pederasty, and also seemingly embraced the kind of lyric acceptance of temporality in the advice to "pluck (carpere) the brief spring of youth." Such are the themes of Orpheus' song and the wisdom he wants to convey to the Thracian community. And the particular ironies of a song that at once aims to teach its audience of the inevitability of time's passage, the lesson Vergil's Orpheus never learned, and seemingly also to escape it emerges when we remember that the specific listeners he tells to "pluck the first flowers" are themselves trees, and indeed trees who, as the absent presence of Cyparissus reminds us, might themselves have been ripe for metaphorical as well as literal plucking.

A closer consideration of those trees helps further connect these generic ambiguities with the contradictory vantage points on temporality. A salient characteristic of these trees, and one much observed is that their own unstable identity matches the proliferation of literary genres that they evoke. ${ }^{29}$ The breakable (fragiles) hazel bushes, like those under which Vergil's pastoral

29 The interpretation of trees as signifiers of different poetic genres/registers goes back to the virtuoso discussion of Pöschl, 1960 (particularly interesting here for 
goat miscarries, are themselves sonically hardened into the quintessentially warlike ash trees (fraxinus), whose literary roots go all the way back to Priam of the good ash spear (10.93). ${ }^{30}$ The trees are anthropomorphized not only because they are endowed with magical motion by Orpheus'song, but because Ovid's own song has taught us to see in several of them an unnamed human presence. ${ }^{31}$ Conversely, as Orpheus sets the wood in motion, that action reminds us that in Ovid becoming a tree means losing the softness and mobility of life in exchange for the hard facts of memory. Thus the trees each figure Orpheus' own literary instability, either as an always elegiac presence renewed in the genres of epic and didactic, or as having lost his defining characteristics by being transformed into the hard but lofty genre of epic. Yet the problem of whether trees connote the mortals who once inhabited them or their highly fixed literary identities itself relates to a fundamental symbolic function of trees in classical literature, as symbols of mortality. In both archaic epic (Il. 6.145-51) and elegy (Mimn., 2.1-8W) we are reminded that the generation of men is like the generation of leaves. Trees juxtapose the brief but recurring produce of fruit and leaves, there to be "plucked", and the diachronic presence that becomes visible as each specific individual disappears. While Ovid's first song is addressed to shades who were once

its emphasis on how sonic effects make the woods themselves echo Orpheus' song). See also, especially, Nagle (1988, 118-20).

30 And the generic interference seems especially heightened through a pattern of cunning and meticulous allusion. Thus in Ennius the hard ash is itself broken, frangitur, (6.177), but Ovid seems to have displaced this property onto the shrubbier hazel. But in respect to Vergil's tree catalog at the beginning of Georgics 2, the transformation works the other way. Because there coryli are not breakable, but, on the contrary, exceedingly hard, edurae, for the feet that trod on them (2.65). Neatly Ovid anthropomorphizes the tree by making us consider that being stepped on is bad for the hazel bush too. But he simultaneously exaggerates a generic contrast between hard and soft the early literary tradition itself blurs.

31 Also emphasized by Ahl $(1985,214)$. 
alive but are now eternally the same, stereotyped figures of the literary landscape, he sings his second song to fixed presences of the literary landscape through which we see the humans who once inhabited them occasionally emerging through the leaves.

The song Ovid's Orpheus produces on this occasion has attracted much attention for its remarkable semantic complexity. One central problem is that the voice of Orpheus seems overly present. Apollo seems to ventriloquize for him when he at once blames and exculpates himself for the death of his beloved Hyacinthus. Pygmalion's ability to bring life to the dead - or rather the tactful displacement of this superhuman power onto the divinity not the artist - seems transparently an exercise in wish fulfillment. Cinyras' recognition of his daughter Myrrha echoes the fatal backward glance that sent Eurydice back to death, and Venus' failed attempt to preserve Adonis fits the same pattern. The Orphic perspective seems therefore to cross gender and species boundaries as it is appropriated by male and female as well as human and divine. In doing so, and in combining the lamentation for his own condition with the assumption of those divine identities that enforce by contrast the mortal constraints that condemn Orpheus to lament, Orpheus' song mimics the doubleness I have been trying to define. He at once manifests and experiences sorrow and he teaches it, viewing mortality from the outside, and indeed putting himself in the very position of the divinities who impose the necessity of Eurydice's return to the dead, and from the subjective perspective of the mourner, as indeed the divinities themselves are transformed by anthropomorphization. Apollo only falls in love in poetry, and when he does he loses his own enduring characteristics.

The complexities of this song have been powerfully analyzed by Micaela Janan and Victoria Rimell, both of whom place particular emphasis on what these narratives tell us about love and desire.Janan, for example, stresses how Orpheus' song promotes a fantasy of desire immune from the loss of control that happens 
when identities merge. Orpheus wants to remedy or avenge his sorrow by casting the blame on a female other, and from now on only loving those who are already the same as he; and the outcomes that show the failure of such a strategy complicate his authority and language within the poem. Yet Janan's piece appeared slightly before a "Roman sexual revolution" that forced a re-evaluation of how ancient categories of sexual behavior match our own. When we name Orpheus' desires homosexual, it inevitably underlines the "sameness" of subject and object within this relationship. But the Romans' highly polarizing descriptions of the participants in sexual intercourse as active or passive impose difference where we might be inclined to see sameness. And so if the particular language Ovid uses can make gender a point of similarity between the poet and his partners, he sets up another boundary between them, one defined by time. The males Orpheus loves are, unlike some of the trees, tender, teneros and they are on "the near side of youth". ${ }^{32}$ The latter distinction conforms of course to common ancient aesthetic preferences for males just at the point of youth - an ephemeral moment often described as here with the imagery of vegetable "flowering". It also, though, highlights a tension with the ideal elegiac relationship, which is everlasting and unchanging. This stress on a difference of age rather than sameness of gender gives a very different perspective on the thematic significance of such desire here. It is the desire not for another identical to one's self, but to one's younger self. And, as we shall see, it is precisely this element of temporal difference that emerges in more exaggerated form when Orpheus gives his own version of his didactic theme. The narrator's description had highlighted "translating" love to males before youth (10.84), but what Orpheus announces as his theme is a specific version of that, boys loved by divini-

32 On the importance of transitional temporal moments in Orpheus' song, see Rimell (2006, 106-9). 
ties (10.152-3). The ephemeral "flower" of youth now stands out all the more by contrast to the immortality of the boys' lovers. ${ }^{33}$

My interpretation of this new Orphic theme takes its cue from a much later comparand that also has an ancestor in a Vergilian underworld. In Canto 15 of Inferno, Dante depicts the punishment of the sodomites as an endless procession, beneath a fiery rain, around the circular trajectory of the seventh level of the underworld. John Freccero demonstrates that the nature of the punishment and the placement of the sinners argues here too against the notion that excessive desire or the particular gender desired alone condemns the sodomites as "violent against nature". Rather it is their pursuit of immortality "by other means"; in this case the succession of teacher and student, linking the figure of Brunetto to his pupil Dante, suggests a desire for worldly fame that displaces other models of generational succession. In particular this lateral motion round and round contrasts with the ideal relationship between father and son that finds its didactic realization in Aeneas' encounter with Anchises in Vergil's epic catabasis, and can be re-interpreted in the Christian transfiguration of worldly experience through the embodiment of the Father in the Son. Of course this particular vertical route to eternity cannot figure in Ovid's poem, but Freccero's analysis of Dante makes a particular sense out of two aspects of Orpheus' song, the way that pederasty translates into problems of representation and immortalization, and, second, the use of incest as a foil to the praise of the love of pueri.

33 Note as well that a different inequality is given in the Ars (2.682-4) as the reason for Ovid's dislike of pederasty: unlike the ideal heterosexual coupling, in which both partners share in the pleasure ex aequo, sexual pleasure with boys is always one-sided. If authentic Ovidian erotodidaxis leads to success, frozen in a moment of amatory bliss that concludes the Ars in both its two-book and three-book forms, Orpheus re-injects a more authentically elegiac note, where what endures is lamentation for lost loves. 
The importance of modalities of immortality as a theme in the song is signaled at its very beginning. As I noted before, the translation of Orpheus from elegy to epos mirrors at once Ovid's succession to Vergil, and the attempt to revise his former elegiac self. So too Orpheus' starting point suggests a resumption and a correction of earlier metamorphic catalogs in the poem. ${ }^{34}$ And here it is striking that Orpheus' song seems at once strictly to follow the rules of hierarchical propriety by beginning as that arch-didactic poem, Aratus' Phaenomena, with Jupiter himself. (And I note in passing that this is a gesture of filiation as well; Jupiter is Orpheus' maternal and paternal grandfather.) This incipit corrects the beginning of Ovid's own epic, which pointedly reverses Aratus' own sequence. In the Phaenomena the sea is full of Zeus, but Ovid's poem takes us back "before the sea" (ante mare, 1.5) not to an intrinsic Zeus, but to a time before metamorphosis was possible because there was only one countenance in all nature, Chaos, a face that is at once a sign of emptiness, if we cleave to its Greek meaning, and all faces indistinguishably merged, according to Ovid's definition of it as rudis indigestaque moles (1.7). But of course at the same time that Orpheus' beginning seems to bring Ovid's back into literary and religious orthodoxy, it is also immensely transgressive. ${ }^{35}$ For the context of this catalog paints Jupiter not in naturalistic terms, but in the hyper-anthropoid and philosophically scandalous guise of a sexual predator. The always elegiac Ovid still seems to be giving form to his gods rather than the other way around.

This face of Ovid's Jupiter emerges more clearly when we measure Orpheus' beginnings not against external poetic norms, but against other didactic catalogs generated within the poem. One internal artist who does begin with Jupiter is

\footnotetext{
34 See also Johnson (2008).

35 Cf. especially the discussion of Barchiesi (1989, 65-6).
} 
of course Arachne, whose catalog of divine rapes opens with Jupiter's deceptions of Europa, Leda, and others (6.103-14). The rape of Ganymede, which similarly requires Jupiter to assume an animal disguise, would seem to continue Arachne's subject, but it differs in important respects. First, Arachne not only concentrates on women, but as Ovid himself had done in his Europa narrative, changes the tenor of the story by leaving out the offspring to focus on the sexual encounter. She is not interested in Minos or Castor and Pollux, and her reference to Jupiter filling Nycteis with offspring seems primarily an aggressive inversion of Aratus' claim that all things are "full" of Zeus. What Arachne's tapestry preserves is of course an accusation of the gods that makes them forever bestial, and an artistic image of the facies of "all" the god's female victims (6.1212). And it is this emphasis on the falsity of the gods' disguises that will be the second important variation in Orpheus' song. Janan reads Jupiter's transformation into an eagle as a sign of the alienating power of desire, that makes even the king of the gods no longer himself $(1988,116-7)$. And the feathers are described, in highly Arachnid terms as "cheating", mendacibus (10.159). Yet from another perspective, Jupiter's choice of form uniquely conveys his identity as much as it masks it. The eagle is, again in rebuttal of Arachne's polymorphic divinity, the only thing into which Jupiter would wish to be changed. And since this form already conveys, through its own unique potency (posset), the identifying weapons of Jupiter; what Jupiter turns himself into here is a sign that can only denote the god himself. And equally importantly, Ganymede too will be enabled to preserve his identity forever, not obviously through the offspring he bears Jupiter, nor through an artistic representation such as Arachne offers Europa, but as himself. ${ }^{36}$

36 See also the similar reading of Hardie $(2002,65)$. 
This beginning thus delicately balances the possibilities of reading Orpheus'song as an eroticized debasement of a didactic poem that could show the truth about the gods, where the minute we see Jupiter, he vanishes into a viciously motivated deception, or rather as a revelation of song as the expression of immortal essences - a Jupiter unchanged by desire, and a youth who escapes from temporality not as a mere sign or image, but as himself. Such a translation of pederastic desire to an artistic aspiration, indeed to the transcendence of the mortal condition, provides a template for reading the imperfect approximations of the pattern that follow. Jupiter's son Apollo, does not elevate his beloved Hyacinthus, who only becomes eternal in a very qualified way (qua licet, aeternus tamen es, 10.164): through annual recurrence as a flower. Nor does this his divine lover remain himself; rather he assumes the paleness of the youth he mourns (10.185-6). The final distance between Adonis and the windflower, and the link of its naming and its disappearance discussed in the previous section, stand out all the more as the polar opposite to Jupiter's blending of erotic success, immortalization, and self-representation at the song's beginning.

Another way Orpheus' sexual preferences figure simultaneously the transience of life and the pursuit of an eternal self is through intratextual comparison to the experience of the poem's most conspicuous earlier male lover of young men, Narcissus. Orpheus has sometimes been described as "narcissistic" in the modern sense of someone whose desires are always ultimately directed towards himself, ${ }^{37}$ but the comparison with Ovid's own Narcissus can help sharpen the significance of this resemblance beyond a vague sense of moral impropriety or psychological pathology. Let us recall for a start that Narcissus

37 For the characterization of the poetic Orpheus as a narcissist, see Anderson $(1989,3)$. 
exists in that transient instant of beauty that an Orpheus most desires. He benefits from the autonomy that such beauty gives him without the suspicion that times will change and the desired will ever come to desire. In larger mythical terms, his ephebic moment, enjoyed, appropriately beyond the reaches of civilization, may remind us of the condition of Hippolytus, whose similar rejection of women and marriage suggests a too close approximation to the divine Artemis. Such absolute purity figures the divine removal from the cyclicality of human life - reproduction and the loss of a beloved - which Hippolytus' mortal status rules out for him. ${ }^{38}$ In Orpheus' case the situation is in some senses very different, because he has married, but in his new grief he pursues a version of Narcissus' ideal isolation, and it is in revenge for this that he is ultimately killed, just as Narcissus' death will be brought about by the reciprocity of Nemesis. However, there is of course one other salient difference between Narcissus and Orpheus. Narcissus rejects lovers of both sexes, while Orpheus has a strongly polar set of preferences, hating women as much as his Hippolytan exemplar, but strongly post-Narcissan in his desire for the reflection of himself. This dichotomy helps make clear both that what begins as the pursuit of autonomy in the case of Narcissus, acquires a retrospective element in the case of Orpheus, who is looking back at the moment of his youth, perhaps as though he never married, and simultaneously the powerful rejection of another mechanism available to humans for transcending their own mortality, that is, offspring. ${ }^{39}$ In this regard it is interesting to note that Orpheus' sexual preferences do not subsist after death

38 For this interpretation of Hippolytus' virginity as an avoidance of temporal transitions, see Goldhill (1986, 120-1). Other allusions to the Hippolytus in Orpheus song have been analyzed by Pavlock $(2009,96-9)$ and M. D. Thomas (1998).

39 For offspring as an alternative to a number of commemorative strategies in the poem, see Meinrath (2014). 
but are reset to an ideal originary desire for Eurydice in the underworld.

And the image of Ser Brunetto in Inferno may perhaps give new significance to another element of Ovid's final portrait of the two lovers, the parity of their steps as they walk through the arva piorum:

$$
\begin{aligned}
& \text { invenit Eurydicen cupidisque amplectitur ulnis. } \\
& \text { hic modo coniunctis spatiantur passibus ambo, } \\
& \text { nunc praecedentem sequitur, nunc praevius anteit } \\
& \text { Eurydicenque suam iam tuto respicit Orpheus. (11.63-6) }
\end{aligned}
$$

As Freccero describes, Brunetto's encounter with his younger protégé Dante will be mapped in a(n all too momentary) spatial displacement around the circular course of the pit, as he lingers to converse with him:

$$
\begin{aligned}
& \text { E quelli: "O figliuol mio, non ti dispiaccia } \\
& \text { se Brunetto Latino un poco teco } \\
& \text { ritorna'n dietro e lascia andar la traccia". } \\
& \text { (Inf. 15.31-3) }
\end{aligned}
$$

As he seems to go back to his earthly existence and to recapture the past in the company of this false son, so his progress slows relative to the group he was originally with. At the end of their conversation, a new group is approaching of which he is forbidden to be a part. He turns back and "seemed one of those who race for the green cloth through the countryside in Verona, and one of those who wins, not loses," (15.121-4). The ambiguous seeming victory of Brunetto in a race that he really has already lost by being a competitor most directly describes the ambiguous place he has come to occupy, so far behind one group that he seems to be the winner among the next. Freccero $(1991,71)$ comments, "if the infernal race were thought of as analogous to the succession of generations, then he would be the man who attempts to pause in the race towards death and so, momentarily, seems to be out of front in the succeeding pack." In a similar way, the dead Orpheus' ability to gaze back on 
Eurydice in safety does more than simply reverse the moment in which he lost her as a mortal presence. The tragic priority that took Eurydice to the underworld before her time and before Orpheus, which Orpheus is powerless to reverse by maintaining the lead or by only looking ahead, emphatically vanishes in this vision of eternity. ${ }^{40}$

But the concluding emphases on being ahead or behind also highlights the role of games and competition in Orpheus' song as a depiction of what lovers do. The only interaction between Apollo and Hyacinthus depicted in the poem is a most unequal certamen, in which Apollo's first throw of the discus proves literally crushing. In the penultimate narrative, Atalanta's experience of sexuality depends on the outcome of a race. As in that contest the playful modulation of her speed in response to the stirrings of Venus contrasts with the circumstance that her defeated suitors really were running for their lives, so the entire imagery of the contest recalls at once the erotic "race" that both lovers only win by finishing at the same time (Ars 2.727), but the race of mortality in which we only win relative to others, always overtaken by those born later. According to an erotic reading of the image, the equal steps of Orpheus after being re-united with Eurydice may signal the return to an original heterosexual

\footnotetext{
40 There, the fatal backward glance forms part of a highly linearized progression. The "law" Persephone gives in the Georgics is simply that Eurydice follow behind (pone sequens, 4.487); and Orpheus breaks it at first not so much by looking backwards as by halting (restitit, 4.490). When Ovid revises this by applying the goddess' prescription simply to the gaze (ne flectat retro sua lumina, 10.51), he also himself casts a glance backwards at this model. The bathetic-seeming detail that Eurydice was still slowed by her wound (10.49) points to the Vergilian emphasis on pace, which Ovid will pick up in turn at their reunion. It further links this imagery specifically to the facts of mortality, since what literally and figuratively slows her is the wound that caused her death. And finally, the humor of the image itself poses a question highly important to the themes of this discussion: do souls participate in material reality? The double reversal in book 11, evoking both Vergil and Ovid's own account of Orpheus' transgression, is also noted by Neumeister (1986, 181).
} 
desire where such a climax is uniquely possible, given Ovid's construction of pederasty as defined by unequal pleasure. But reflection on other paradigms of the race create an extremely polarized reading. Hector's death may be imagined as a footrace, but only to have the ludic aspect of that image immediately rejected. He is running for his life, and will never be re-united with the wife who gazes at him from the uncrossable boundary of the walls. The quality of interference between the different generic associations of the language in which Orpheus and Eurydice's re-union is described serves perhaps to superimpose an epic seriousness about mortality and a didactic lesson about replacement on the subject of elegiac desire, but it does so only at the risk of pulling the integrity of the discourse apart, by subjecting the weightier readings of the episode to the suspicion of parody, but conversely by suggesting that such stylized erotic happy endings exist only in stories, as a fantastical and highly literary conceit as removed from any real struggle for immortal existence as the poetic underworld is from the reality of death.

A similar kind of generic self-consumption by which Orpheus' song constructs two antithetical readings of its aims and success appears when we try to understand his pre-occupation with incest in terms not of his own pathological wish to displace the guilt he feels for Eurydice's loss onto women but rather as illuminated by his emphasis on the pursuit of eternal presence through desire. The emphatic revulsion Orpheus focuses on children as objects of desire highlights by contrast the opposing idealization of objects of desire taking the place of children. When Jupiter makes Ganymede immortal in the face of Juno's hostility, we may think of this as another example of the queen of the gods characterized as perpetually jealous of erotic rivals like Semele, whatever their gender. But Juno is of course equally vengeful against the children of these unions, such as Hercules and Dionysus. And this whole motif may recall 
the more ancient rivalry between the male and female based on reproductive capacities. Zeus' ability in the Theogony to produce an offspring that will always represent but never succeed him, contrasts with the rebellious and misbegotten parthenogenetic children of Hera and Gaea. ${ }^{41}$ (It was these very earth-born giants whose defeat Orpheus used to sing about, 10.150-1.) In this case, the immortalization of the youth Ganymede may be as much about the production of an immortal offspring as an immortal erotic rival. So too the lover in the next song is also a father, the poet's own genitor (10.167), juxtaposing Orpheus the offspring who emulates his father as a singer with the only cyclically immortal youth whom that father "loved before all others". Although Ovid uses diligere almost exclusively in erotic contexts, since it can in Latin be commonly used of offspring (TLL, s.v. 1177.81ss.), one wonders whether Orpheus' ante omnes here also implies a comparison with his father's love for him as his child. And when Venus falls in love with Adonis, she does so after a potentially incestuous encounter with her own son, Cupid - pierced by his weapon in the midst of kisses (10.5258). ${ }^{42}$ And the person with whom she falls in love, Adonis, had just been figured as the visual image of that child (10.515-8).

This substitution for the child by the beloved also inflects the particular aspirations and nature of Orpheus' song. I have argued that in relation to the first of Orpheus' themes "boys loved by the gods" (10.152-3), we should place the emphasis on the disparity of duration between gods and boys as much as their sexual sameness. When gods love youths it prompts at once a prospect of immortality for a beloved youth, and after the first normative example of such desire actually fulfilled in Jupiter and Ganymede, provides an unceasing and recurrent

41 Zeitlin (1995, 108).

42 See M. D. Thomas (1998, 102-3); Hardie (2002, 187-8), and Pavlock (2009, 96-7). 
source of song as mourning. When mortal offspring desire their parents it reveals by contrast the parents' age and can serve as the accusation of song itself. Orpheus, introducing the story of Myrrha, who conforms to his second theme (women struck by illicit desire, 10.153-4) he worries about the seductive capacities of his own song, and counters by stripping it of its fundamental didactic pre-requisite fides. (And this seems a very Ovidian gesture in combining his ironic defense of the Metamorphoses as untrue, e.g. at Tr. 2. 64, with his defense of Ars as not actually transforming morality, Tr. 2.307-14.) Thus the same song that translates the loss of the beloved into a lamentation for the transience of mortality from the perspective of divinities, can simultaneously emerge as a transgressive attempt to transcend the limits of nature. As the speaker whose real presence must be emphatically denied, Myrrha, wants to be like the gods through incest, so the song comes to police and accuse itself. Its ultimate failure as a mode of propagation now seems willed by a poet who rejects the existence of its subject, while the elegiac perpetuation of mourning derived from failure compensates for the inevitability of change. If Orpheus had not lost Eurydice he would never have sung, or rather his voice would never have reached us, since his only earlier song, the cletic hymn to Hymenaeus, is mentioned but not represented. As elegy, song's failure is its success, while as didactic its success, its ability to inspire fides and emulation, to persuade the gods of the underworld to end their empire, or to provide an exemplum for mortal girls of the divine pleasures of incest, would be a transgression. Elegy can become didactic if it teaches limitations as well as attempting to overcome them, but it cannot ever succeed in providing a reliable means of reproduction, like Vergilian didaxis.

To help parse how reproduction and remembrance correlate with the paradoxical combination of transcendence and transgression in Orpheus'song, let us press the issues of literary genealogy and biological paternity a little farther. The starting point for Freccero's reading of Dante's Brunetto is the contrast 
between this pederastic literary father and the capacity of real fathers to set their offspring on a track back to life on earth. And one of the paradigms for this ideal poetic act of instruction is Vergil's own Anchises. At that moment in Vergil's epic, the georgic bees propagated through Aristaeus song take on substance as Aeneas sees offspring who will become real in history (Aen. 6.707). But he also re-enacts and displaces the moment of Orphic failure when the son's inability to grasp his father's shade at once repeats and transforms the poet's loss of his beloved Eurydice: Aeneas gains a future sine fine for the sacrifice of a return to/of the past. Orpheus' second song in the Metamorphoses does not teach successions of generations becoming real. As it replaces sons with lovers, so it simultaneously re-casts the relationship between real parents and children as erotic transgression. ${ }^{43}$ In generic terms, by sticking with the authentic Orpheus, as opposed to his "successor", in terms only of Vergil's literary production, Aeneas, Ovid may seem to be highlighting the pre-eminence of an elegiac over a didactic voice, but he is also transforming the capacity of the two genres to define one another. He brings out the erotic in the "real" human succession that at once necessitates didactic poetry and provides the medium for its propagation, as fathers teach their offspring what they need to know about the nature of life. In doing so he re-casts that mechanism of succession and that poetic tradition as repugnant, and a violation of limits precisely because of the kind of immortality it promises. By contrast in giving elegy the long temporal reach of epic and the persuasiveness of didactic, he makes the failures of desire compete with the lessons of epic "success"ion as the truest kind of instruction.

Orpheus'emphasis on pederasty thus reciprocally deforms the programmatic relationship that figures and inspires poetic

\footnotetext{
43 As the phrase "sons and lovers" reveals, this argument about the slippage between erotic objects and offspring is much indebted to Oliensis' (1997) analysis of a similar tension in the Aeneid.
} 
production for both elegy and epic/didactic. In comparison to elegy, the Orphic substitution of relationships between those different in age for those different in gender sets that genre's interest in unending love and lament on an epic scale. The disparity between dying boys and immortal divinities pushes the contrast between mortality and immortality to the extreme, and substitutes for the elegiac poet, claiming to love throughout his life and recognized as a lover at the moment of his death, an ambition for escaping the cycle of mortality. By contrast, the substitution of relationships based on subjective erotic desire for those based on genealogical succession hints that even the licit and recognizably mortal strategies of ideological reproduction, through the training of like-minded offspring and a poetic strategy grafted to such propagation, have their roots in the same individual desire for immortality. And this can appear as transgressive within the theogonic frame of myth as the alliance between imperial propagation and desire can in terms of contemporary ideological polarities. In return, the model of the elegiac poet's voice surviving alone as a record of loss makes it possible to hear Orpheus' didaxis in new ways. It is now the poet's voice and not the wisdom he represents that endures. Orpheus' end perfectly depicts this, for he survives both as a disembodied voice in this world, and as an unreal presence in the underworld, where he loves Eurydice with a fervor, timelessness, and reciprocity that fulfills all the desires embodied in a Propertian or Tibullan underworld. But just as he will never cross the threshold back to reality, so we need never believe in his existence there as anything other than a poetic fantasy.

The Orpheus who matches his steps with Eurydice in this fictive underworld may seem to return via Ovid's text to a version of the conceptual space he occupies in the Georgics. There 
he was constrained and limited by a series of geographic rivers, marking the boundaries of Thrace as they do of the underworld, that figure the containment of his own desires and mechanisms for achieving them within the compass of a didactic poem that itself crosses oceans to put the mythical artes of distant cultures to work in the real soil of Italy. Yet balancing the Orpheus who is described in this way, emerges another who makes the world echo his song, and whose presence is heard through the chain of voices that seemingly distance him from Vergil's text. My aim in this paper has been to show how Ovid's treatment of Orpheus inserts his own poem into both dimensions of the Vergilian tradition. In doing so, he interrogates and further destabilizes the doubled presence of Orpheus established there through what I have loosely called elegiac and didactic readings of his predecessor's poem. But equally important is the way he deploys those alternative perceptions of poetry to manifest central themes of his own work. An Orphic Metamorphoses does more than take Ovidian epic back to its roots in elegy, it fundamentally doubles the voice of the poet and locates its source inside and outside his text. The narrating Ovid who seems nowhere more in control of his narrative than when he so transparently engages the work of a literary predecessor, simultaneously appears as possessed by the voice that text generates and ultimately ends in the same place as Orpheus and Vergil before him, at a boundary between the past he can describe and the future he can only really occupy as a voice himself. His poem as a whole, like the goddess whose words Orpheus takes over at the conclusion of his song, speaks the "law" to which he is subject. Yet that law controverts itself by naming, and making any reader name, the lost figure of Eurydice. Arguably no aspect of Ovid's poem is more present in the world of its audience, more undeniably immanent than the sounds it produces from the mouths of its readers. An effort to hear an Orphic voice makes this present phenomenon at once signify merely the prompts of a tradition of earlier texts that 
produce vibrating echoes in the air, and re-configure that breath as the surviving animae of a series of lamented souls.

At the border between the between the depiction of Orpheus as a living sonic presence, making the river banks echo his flebile nescioquid, and an Orpheus who has, so to speak returned to script in the arva piorum, comes a final figure at once of finality and re-birth, the serpent who bites the poet's severed head, or was about to when Apollo freezes his gaping mouth open. The resulting silence makes the serpent itself an emblem of Young's account of Orpheus' condemnation simply to being a part of literary history by an act of writing that silences his voice. Her own memorable treatment of the scene, however, stresses at once the corporeal vulnerability of the serpent's victim and how the sibilants in Ovid's narrative manifest to the reader this very moment of bodily danger. ${ }^{44} \mathrm{I}$ would like to conclude by further considering the doubleness of the serpent. An interpretation of it as a symbol of script suggests its ability not just to figure Ovid's text but to figure immediately within it. While I cannot find any evidence that the ancients interpreted it so, the very shape of the serpent suggests various graphic features of the Ovidian page. While Orpheus' name may begin "orally" and progress through the onomatopoetic lament "beu" it ends with what Ben Jonson calls "the serpent's letter". And this name forms the last word of Ovid's narrative (11.66). ${ }^{45}$ But, as Young describes, the serpent is as much a heard as a graphic presence in Ovid's poem. The letters that may make Ovid's poem reflect that hardened visual monument produced by Apollo also echo its own sibilant voice. On the one hand, the snake that killed Eurydice and then threatens Orpheus' os, traces a progression in the text, literally

44 Young $(2008,1)$.

45 Based on Barchiesi's (1997, 190-91) description of a similar closural serpent in book 15, I wonder whether a coronis, the paratextual marker that separates the individual poems in a manuscript, may similarly have coiled beside this textual boundary within the poem. 
from head to toe, or heel to face, that signals the inescapable recurrence of death. (Or perhaps its transcendence, since its proverbial sting is thwarted at last by the actions of Apollo.) It is always the same, and its hissing may be heard as well as seen in both the underworld passages it introduces:

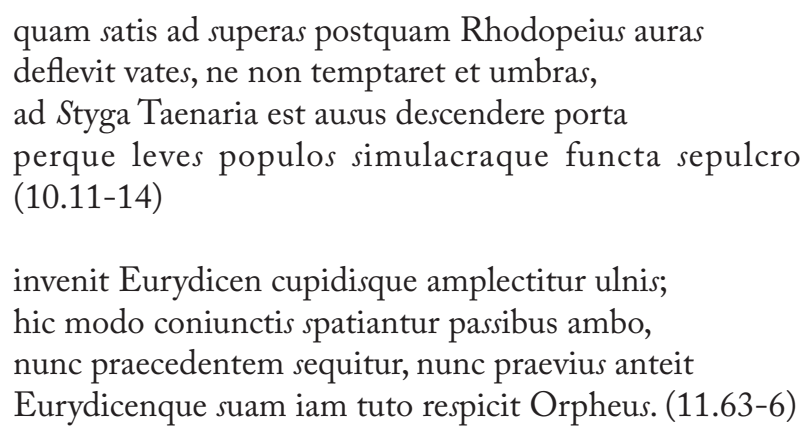

These sonic and visual echoes, the latter perhaps mirroring too the rivers that enclose the Orphic textual landscape as much in Ovid as they do in Vergil, make it an all too apt closural device. ${ }^{46}$ Yet the very actions the lovers perform in the underworld, their embracing, and not least the passibus by which now one and now another advances, equally give their life after death a serpentine quality. As much as a demarcation we may choose to see the serpent as marking a return, and imagine him as a figure for the recovery of the past as much as its loss, a kind of ouroboros ${ }^{47}$ that marks the beginning of Orpheus as much as its ending.

46 Genovese (1983, 152): "Like the epic in which it is set, [the Orpheus-Eurydice story] begins and ends with a serpent."

47 In a class discussion of this passage in fall 2014, one of my Princeton students, Miles Hinson, asked about the image of the serpent as ouroboros, and I happily acknowledge my debt to this perception. 


\section{Bibliography}

Ahl, F. 1985. Metaformations. Ithaca: Cornell University Press.

Alpers, P. 2013. "Apostrophe and the Rhetoric of Renaissance Lyric." Representations 122: 1-22.

Anderson, W. A. 1982. "The Orpheus of Virgil and Ovid: Alebile nescio quid." In Orpheus: The Metamorphoses of a Myth,J.Warden, ed., 25-50. Toronto: University of Toronto Press.

1989. "The Artist's Limits in Ovid: Orpheus, Pygmalion, and Daedalus." Syllecta Classica 1: 1-11.

Barchiesi,A.1989."Voci e istanze narrativi nelle Metamorfosi di Ovidio." MD 23: 55-97.

1997. "Endgames: Ovid's Metamorphoses 15 and Fasti 6." In: Classical Closure, D. H. Roberts, F. M. Dunn, and D. Fowler, eds., 181208. Princeton: Princeton University Press.

, ed., 2005. Ovidio: Metamorfosi. Volume I: Libri I-II. Milan: Fondazione Lorenzo Valla.

Batstone, W. 1997. "Virgilian Didaxis: Value and Meaning in the Georgics." In The Cambridge Companion to Virgil, C. Martindale, ed., 125-44. Cambridge: Cambridge University Press.

Butler, S. 2011. The Matter of the Page: Essays in Search of Ancient and Medieval Authors. Madison: The University of Wisconsin Press.

2015. The Ancient Phonograph. Brooklyn: Zone Books.

Cucchiarelli, A.,ed., 2012. Publio Virgilio Marone: Le Bucholiche. Rome: Carrocci Editore.

Farrell, J. 1992. "Dialogue of the Genres in Ovid's 'Lovesong of Polyphemus'(Metamorphoses 13.719-897).” AJP 113: 235-268.

Freccero, J. 1991. "The Eternal Image of the Father." In The Poetry of Allusion: Virgil and Ovid in Dante's Commedia, R. Jacoff and J. T. Schnapp, eds., 62-76. Palo Alto: Stanford University Press.

Gale, M. 2007. Myth and Poetry in Lucretius. Cambridge: Cambridge University Press.

Gärtner,T.2008."Die hellenistische Katalogdichtung des Phanokles über homosexuelle Liebesbeziehungen. Untersuchungen zur tendenziellen Gestaltung und zum literarischen Nachleben." Mnemosyne 61: 18-44. 
Genovese, E. N. 1983. "Serpent Leitmotif in the Metamorphoses." In Studies in Latin Literature and Roman History III, C. Deroux, ed., 14155. Brussels: Éditions Latomus.

Goldhill, S. 1986. Reading Greek Tragedy. Cambridge: Cambridge University Press.

Hanson, J. A. 1982. "Vergil." In Ancient Writers: Greece and Rome, T. J. Luce, ed., 669-701. New York: Charles Scribner's Sons.

Hardie, P. 2002. Ovid's Poetics of Illusion. Cambridge: Cambridge University Press.

Heine, M. 1868. Erinnerungen an Heinrich Heine und seine Familie. Berlin: F. Dummler Verlag.

Hinds, S. 1998. Allusion and Intertext. Cambridge: Cambridge University Press.

Janan, M. 1988. "The Book of Good Love? Design versus Desire in Metamorphoses 10." Ramus 17: 110-137.

Johnson, P. 2008. Ovid Before Exile: Art and Punishment in the Metamorphoses. Madison, Wisc: University of Wisconsin Press.

Knox, P. 1986. Ovid's Metamorphoses and the Traditions of Augustan Poetry. Cambridge: Cambridge University Press.

Leach, E.W.1974. "Ekphrasis and the Theme of Artistic Failure in Ovid's Metamorphoses." Ramus 3: 102-42.

Lowrie, M. 2009. Writing, Performance, and Authority in Augustan Rome. Oxford: Oxford University Press.

Makowski,J. F. 1996. "Bisexual Orpheus: Pederasty and Parody in Ovid.” CJ 92: 25-38.

Meinrath, D. 2014. Leading (and Reading) by Example: Exemplarity in Ovid's Metamorphoses. Diss. Princeton University.

Nagle, B. R. 1988. "Two Miniature Carmina Perpetua in the Metamorphoses: Calliope and Orpheus." GB 15: 99-125.

Neumeister, C. 1986. "Orpheus und Eurydike. Eine Vergil-Parodie Ovids (Ov. Met. X.1-XI.66 und Verg. Georg. IV.457-527).” WJA 12: 169-81.

Oliensis, E. 1997. "Sons and Lovers: Sexuality and Gender in Virgil's Poetry." In The Cambridge Companion to Virgil, C. Martindale, ed., 294311. Cambridge: Cambridge University Press. 
. 2009. Freud's Rome: Psychoanalysis and Latin Literature. Cambridge: Cambridge University Press.

Parry, A. 1972. “The Idea of Art in Virgil's Georgics.” Arethusa 5: 35-52.

Pavlock, B. 2009. The Image of the Poet in Ovid's Metamorphoses. Madison, Wisc: University of Wisconsin Press.

Pöschl, V. 1960. "Der Katalog der Baüme in Ovids Metamorphosen.” In Medium Aevum Vivum: Festschrift für Walter Bulst, H.R. Jauss and D. Schaller, eds., 13-21. Heidelberg: Carl Winter Verlag.

Primmer, A. 1979. "Das Lied des Orpheus in Ovids Metamorphosen." Sprachkunst 10: 123-37.

Reed, J., ed. 2013. Ovidio Metamorfosi. Volume V: Libri X-XII. Milan: Fondazione Lorenzo Valla.

Rimell, V.2006. Ovid's Lovers: Desire, Difference, and the Poetic Imagination. Cambridge: Cambridge University Press.

Rosati, G. 2002. "Narrative Techniques and Narrative Structures in the Metamorphoses." In Brill's Companion to Ovid, B. W. Boyd, ed., 271-304. Leiden: Brill Publishers

Segal, C. 1993. Orpheus: The Myth of the Poet. Baltimore: Johns Hopkins University Press.

1998. “Orpheus' Metamorphic Bodies: Art, Gender, and Violence in the Metamorphoses.” Arion 5:9-41.

Thomas, M.D. 1998. “Ovid's Orpheus: Immoral Lovers, Immortal Poets.” MD 40: 99-109.

Thomas, R., ed. 1988. Virgil: Georgics. 2 Vols. Cambridge: Cambridge University Press.

Wheeler, S. M. 1999. A Discourse of Wonders. Philadelphia: University of Pennsylvania Press.

Young, E. M. 2008. "Inscribing Orpheus: Ovid and the Invention of a Greco-Roman Corpus.” Representations 101: 1-31.

Zehnacker, H. 1993. "Sur quelques aspects de l'oralité dans la poésie d'Ovide.”In Beiträge zur mündlichen Kultur der Römer (=ScriptOralia 47), G. Vogt-Spira, ed., 159-76. Tübingen: Gunter Narr Verlag.

Zeitlin, F. 1995. Playing the Other. Chicago: University of Chicago Press. Ziogas, I.2013. Ovid and Hesiod. Cambridge: Cambridge University Press. 